\title{
STUDI OPTIMASI PENENTUAN UNSUR HARA BESI DALAM CAMPURAN TANAH DAN KOMPOS MENGGUNAKAN METODE SPEKTROFOTOMETRI
}

\author{
Refilda, Suhartini and Indrawati \\ Laboratorium Kimia Lingkungan, Jurusan Kimia FMIPA, Universitas Andalas, Jurusan \\ Kimia FMIPA Unand, Kampus Limau Manis, 25163 \\ e-mail: refilda_59@yahoo.com
}

\begin{abstract}
Determination of iron nutrient content in a mixture of soil and compost with spectrophotometric method has been carried out. Metal ions Fe(II) complexed with $0.1 \%$ ortho-fenantrolin $2 \mathrm{~mL}$, $0.01 \mathrm{M}$ citric acid as reducing agent using acetat buffer at $\mathrm{pH} 4.5$ and its complex was measured by using spectrophotometer UV/Vis at wavelength $515 \mathrm{~nm}$, the complex stability for was 60 minutes. The highest nutrient of iron with content in soil:compost with ratio of 0.8:0.2 was $0.92 \%$ at incubation time 30 days. The lowest iron content in the mixture of soil:compost (1:0) at incubation time for 15 days was $0.58 \%$ that obtained by the regression equation $y=$ $95.85 \mathrm{x}+0.025$ with $\mathrm{R}^{2}=0.992$. The level of nutrient iron in compost obtained lower than the maximum regulated by SNI $2.00 \%$.
\end{abstract}

Keywords: compost, soil, nutrient element iron, UV/Vis

\section{PENDAHULUAN}

Pengembangan pertanian saat ini lebih banyak diarahkan pada pemanfaatan lahan yang mempunyai produktivitas sangat rendah. Sehingga dibutuhkan pemeliharaan dan peningkatan kandungan bahan organik tanah dalam sistem produksi pertanian. Peningkatan bahan organik terhadap tanah dapat dilakukan dengan cara pemberian pupuk. Pupuk yang biasa digunakan ialah pupuk organik dan pupuk anorganik. Pupuk anorganik jika digunakan berkali-kali maka dapat merusak kualitas tanah, sehingga pupuk organik lebih cocok digunakan dalam memperbaiki kualitas tanah. Selain itu, pupuk organik tidak merusak lingkungan. Salah satu pupuk organik yang digunakan ialah pupuk kompos. Pupuk kompos merupakan pupuk organik yang dibuat dari daun-daunan, jerami, alang-alang, rumput-rumputan, dedak padi, batang jagung, serta kotoran hewan yang telah mengalami proses dekomposisi oleh mikro organisme pengurai, sehingga dapat dimanfaatkan untuk memperbaiki kualitas tanah.
Pemanfaatan sampah organik perkarangan sebagai bahan pembuat kompos dengan aktifator EM4 sudah dilakukan. Pada kompos yang telah dibuat tersebut telah ditentukan unsur-unsur hara seperti $\mathrm{Zn}, \mathrm{Cu}$, dan $\mathrm{Pb}$ menggunakan metode SSA (Spektrofotometri Serapan Atom) $)^{[1]}$.

Unsur-unsur hara yang lain ialah logam Fe. Dimana pada penelitian sebelumnya telah ditentukan kandungan logam $\mathrm{Fe}$ dalam kompos yang dibuat dari tandan kelapa sawit menggunakan Spektrofotometri Serapan Atom (SSA) ${ }^{[2]}$.

Logam $\mathrm{Fe}$ ini juga dapat dianalisa menggunakan spektrofotometri UV/Vis. Penelitian terdahulu menggunakan pengompleks orto-fenantrolin dan 1,10 penantolin hidroklorida untuk melakukan analisa $^{[3,4]}$. Logam $\mathrm{Fe}$ didalam tanah dalam bentuk Fe(II), sehingga dibutuhkan pereduksi untuk membentuk Fe(II). Logam Fe didalam tanah berfungsi sebagai pelaksana pemindahan elektron dalam proses metablisme dan pada tanaman berfungsi sebagai membentuk zat hijau daun pada klorofil. Tanah sebagai media pertumbuhan 
tanaman dapat pula tercemar oleh logam berat. Logam berat yang terkandung dalam tanah tersebut akan berpengaruh terhadap kandungan unsur yang ada pada tanaman ${ }^{[5]}$.

Orto-fenantrolin merupakan reagen organik dengan $\mathrm{Mr}=198,22 \mathrm{~g} / \mathrm{mol}$. Fe(II) dapat dianalisa pada panjang gelombang $515 \mathrm{~nm}^{[3]}$. $\mathrm{Fe}$ (II) dengan orto-fenantrolin memiliki warna kompleks merah jingga. Kompleks yang terbentuk stabil pada $\mathrm{pH}$ 2-9 dan stabil pada waktu yang cukup lama yakni selama 60 menit $^{[6]}$.

Penelitian kali ini dilakukan untuk menentukan kandungan unsur hara besi dalam campuran tanah dan kompos menggunakan pengompleks orto-fenantrolinn dan dianalisa menggunakan spektrofotometri $\mathrm{UV} / \mathrm{Vis}$.

\section{METODOLOGI PENELITIAN}

\section{Bahan Kimia, Peralatan dan Instrumentasi}

Bahan-bahan yang digunakan pada penelitian ini adalah Pupuk kompos yang dibuat dari sampah perkarangan, tanah perkarangan, $\mathrm{C}_{2} \mathrm{H}_{8} \mathrm{~N}_{2}$ (p.a) (orto-fenantrolin), $\mathrm{FeCl}_{3} \cdot 6 \mathrm{H}_{2} \mathrm{O}$ (p.a) (besi(III)klorida), $\mathrm{CH}_{3} \mathrm{COONa} .3 \mathrm{H}_{2} \mathrm{O}$ (natrium asetat hidrat) (teknis), $\mathrm{CH}_{3} \mathrm{COOH}$ glacial (asam asetat glacial) (p.a), akuades, dan asam sitrat.

Peralatan yang digunakan spektrofotometer UV/Vis (Genesys 20 Thermo Cientific), neraca analitis (Metler), $\mathrm{pH}$ meter (Metler), dan peralatan gelas yang biasa digunakan di laboratorium.

\section{Prosedur Penelitian}

\section{Pembuatan Pupuk Kompos dari Sampah Perkarangan}

Kompos dibuat dari sampah-sampah organik pekarangan seperti daun-daun segar yang telah dipisahkan dari ranting-ranting pohon. Daun-daun tersebut dipotong dengan ukuran yang lebih kecil dan dihomogenkan, setelah itu disiram dengan air sampai daun-daun tersebut basah. Ditambahkan $25 \mathrm{~mL}$ aktifator EM4 dan $25 \mathrm{~mL}$ gula aren $(1 \mathrm{~kg} / 500 \mathrm{~mL})$ untuk $25 \mathrm{~kg}$ sampah organik secara merata dan diaduk, dimasukkan ke dalam komposter dan ditutup. Dilakukan pengadukan sekali seminggu sampai komposnya matang. Kompos yang telah matang diayak dan didapatkan kompos halus.

\section{Pembuatan Variasi Komposisi Campuran Tanah dan Kompos}

Sampel tanah dan kompos dicampurkan dengan berat 50 gram dengan variasi komposisi tanah : kompos yaitu $1: 0 ; 0,8: 0,2$; $0,6: 0,4 ; 0,4: 0,6 ; 0,2: 0.8 ; 0: 1$ di dalam gelas plastik. Sampel tersebut di inkubasi dengan variasi waktu $(0,15,30,45,60$, dan 75 hari). Sampel yang diinkubasi tersebut disiram setiap pagi.

\section{Penentuan Kadar Air Sampel}

Sampel ditimbang 1,0000 gram dalam cawan penguap yang telah diketahui beratnya. Kemudian dipanaskan di dalam oven selama \pm 2 jam pada suhu $105^{\circ} \mathrm{C}$. Setelah itu didinginkan di dalam desikator. Setelah dingin ditimbang. Lakukan sampai berat penimbangan konstan.

\section{Dekstruksi Sampel}

Setiap sampel yang akan diteliti di dekstruksi terlebih dahulu dengan mengambil masingmasing sampel sebanyak 0,5000 gram dan dimasukkan kedalam labu Kjeldahl, kemudian ditambahkan $5 \mathrm{~mL} \mathrm{HNO}_{3}, 0,5 \mathrm{~mL}$ $\mathrm{H}_{2} \mathrm{O}_{2}$, dan dibiarkan 30 menit supaya bereaksi sempurna, lalu dipanaskan dengan mantel pemanas sampai uap kuning habis dan larutan menjadi jernih, biarkan sampai dingin dan disaring agar mendapatkan ekstrak jernih. Diencerkan hingga volume tepat 50 $\mathrm{mL}$ dengan $\mathrm{HCl} 0,01 \mathrm{M}$, dikocok hingga homogen. Masing-masing sampel ditentukan kadar airnya.

\section{Pembuatan Larutan Standar $\mathrm{FeCl}_{3} \cdot 6 \mathrm{H}_{2} \mathrm{O}$ $0,2 M$}

Ditimbang 5,4100 gram $\mathrm{FeCl}_{3} \cdot 6 \mathrm{H}_{2} \mathrm{O}$. Dimasukkan kedalam labu ukur $100 \mathrm{~mL}$, dilarutkan dan diencerkan sampai tanda batas dengan akuades.

Pembuatan Standar
CH $_{3}$ COONa.3 $\mathrm{H}_{2} \mathrm{O}$ 0,2 $\boldsymbol{M}$
Ditimbang 2,7000 gram $\mathrm{CH}_{3} \mathrm{COONa}{ }_{3} \mathrm{H}_{2} \mathrm{O}$,
dimasukkan ke dalam labu ukur $100 \mathrm{~mL}$.
dilarutkan dan diencerkan sampai tanda batas
dengan akuades.




\section{Pembuatan Kurva Kalibrasi Standar $\mathrm{FeCl}_{3} .6 \mathrm{H}_{2} \mathrm{O}$}

Dibuat variasi konsentrasi $\mathrm{FeCl}_{3} \cdot 6 \mathrm{H}_{2} \mathrm{O}(0$; 0,$002 ; 0.004 ; 0,006$, dan $0,008 \mathrm{M}$ ), masingmasingnya dimasukkan ke dalam labu ukur $25 \mathrm{~mL}$ yang sebelumnya telah dimasukkan terlebih dahulu larutan asam sitrat $0,02 \mathrm{M}$. Ditambahkan larutan buffer asetat $\mathrm{pH} 4,5$ masing-masingnya sebanyak $5 \mathrm{~mL}$. Kemudian ditambahkan o-fenantrolin 0,1\% sebanyak $2 \mathrm{~mL}$. Ditambahkan akuades sampai tanda batas, dikocok sampai homogen dan dibiarkan selama 60 menit. Diukur absorban pada panjang gelombang $515 \mathrm{~nm}$.

\section{Pengukuran Kadar Unsur Hara Besi pada Sampel}

Ke dalam labu $25 \mathrm{~mL}$ dimasukkan larutan buffer asetat $\mathrm{pH} 4,5$ sebanyak $5 \mathrm{~mL}$, dan 1 $\mathrm{mL}$ sampel hasil dekstruksi campuran kompos dan tanah . $5 \mathrm{~mL}$ larutan asam sitrat $0,02 \mathrm{M}$, dan $2 \mathrm{~mL}$ larutan o-fenantrolin $0,1 \%$, diencerkan sampai tanda batas, dan diukur setelah 60 menit pada panjang gelombang $515 \mathrm{~nm}$.

\section{HASIL DAN PEMBAHASAN}

\section{Serapan Maksimum Kompleks Fe(II) Orto-Fenantrolin}

Penyerapan maksimu dari $\mathrm{Fe}(\mathrm{II})$ ortofenantrolin dapat dilihat dari Gambar 1.

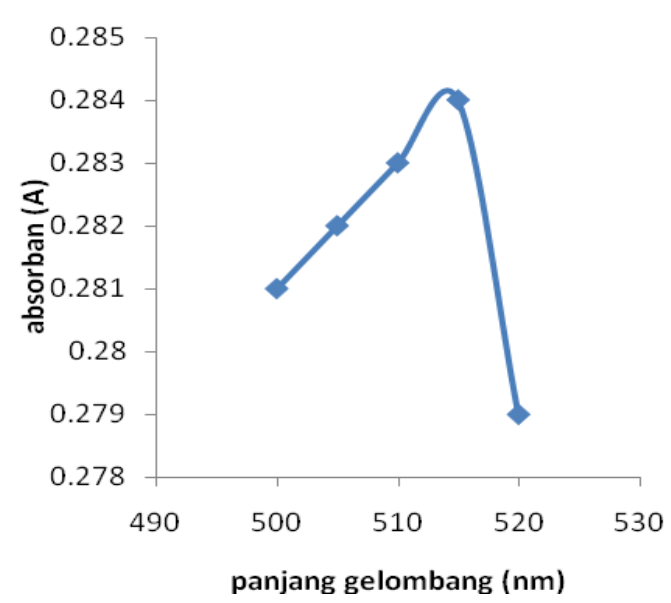

Gambar 1. Kurva penyerapan maksimum $\mathrm{Fe}(\mathrm{II})$ orto-fenantrolin
Dari Gambar 1 dapat terlihat bahwa penyerapan maksimum terjadi pada panjang gelombang $515 \mathrm{~nm}$. $\mathrm{Fe}(\mathrm{II})$ dengan pengompleks orto-fenantrolin dapat diserap pada panjang gelombang $515 \mathrm{~nm}$. Ortofenantrolin $\left(\mathrm{C}_{12} \mathrm{H}_{8} \mathrm{~N}_{2}\right)$ merupakan komponen nitrogen heterosiklik yang dapat bereaksi dengan berbagai jenis logam, seperti besi untuk membentuk kompleks berwarna kuat. ${ }^{7}$ Reaksi yang terjadi antara Fe(II) dengan ortofenantrolin ialah sebagai berikut:

$$
\mathrm{Fe}^{2+}+3 \mathrm{C}_{12} \mathrm{H}_{8} \mathrm{~N}_{2} \leftrightarrow\left[\mathrm{Fe}\left(\mathrm{C}_{12} \mathrm{H}_{8} \mathrm{~N}_{2}\right)_{3}\right]^{2+}
$$

\section{Pengaruh pH terhadap Kestabilan Kompleks Fe(II) Orto-Fenantrolin}

Dalam menentukan $\mathrm{pH}$ optimum, ditambahkan buffer asetat ke dalam larutan. Buffer asetat yang digunakan dari range $\mathrm{pH}$ 3,5-5,5. Nilai absorban dapat dilihat dari grafik di Gambar 2. Dari grafik terlihat bahwa kestabilan kompleks dari Fe(II)ortofenantrolin pada $\mathrm{pH}$ 4,5. Jika $\mathrm{pH}$ yang diberikan besar dari 4,5 maka akan terbentuk endapan dan akan menghambat penyerapan yang terjadi. Hal ini dapat ditinjau dari nilai $\mathrm{Ksp} \mathrm{Fe}(\mathrm{OH})_{2}$ sebesar $7,9 \times 10^{-15}$.

\section{Waktu Kestabilan Kompleks Fe(II)Orto- Fenantrolin}

Tujuan waktu pengompleks dilakukan untuk menentukan kestabilan kompleks Fe(II)ortofenantrolin. Dimana kita tahu bahwa suatu senyawa dapat dikomplekskan dengan pengompleks yang spesik pada waktu tertentu. Data yang didapat dapat dilihat pada Gambar 3. Waktu kestabilan kompleks dapat berlangsung selama 60 menit. Hal ini disebabkan karena kompleks antara Fe(II) dengan orto-fenantrolin stabil setelah 60 menit.

\section{Pengaruh Jumlah Volume Orto- Fenantrolin terhadap Kompleks yang terbentuk}

Divariasikan volume orto fenantrolin bertujuan untuk menentukan berapa volume maksimal pengompleks yang cocok untuk mengomplekskan logam $\mathrm{Fe}$ di dalam suatu sampel sehingga kita dapat menghasilkan penyerapan maksimal yang terjadi. Data yang didapat dapat dilihat pada kurva di Gambar 4. 


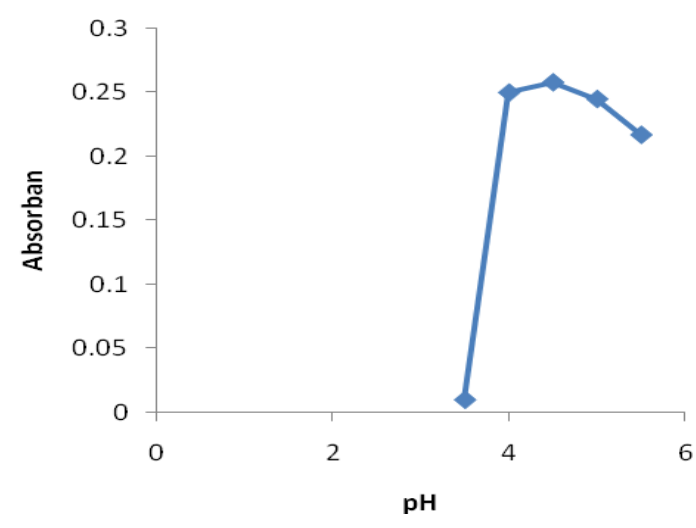

Gambar 2. Kurva pengaruh $\mathrm{pH}$ terhadap kestabilan kompleks Fe(II)

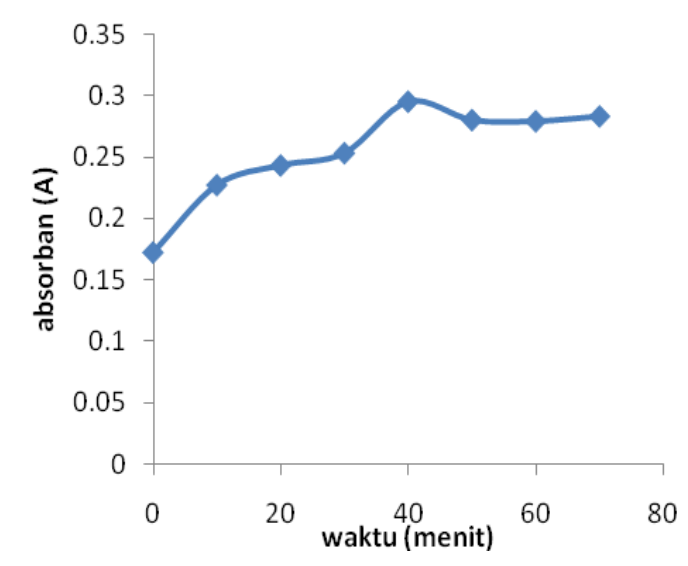

Gambar 3. Kurva pengaruh waktu terhadap kestabilan kompleks orto-Fe(II)

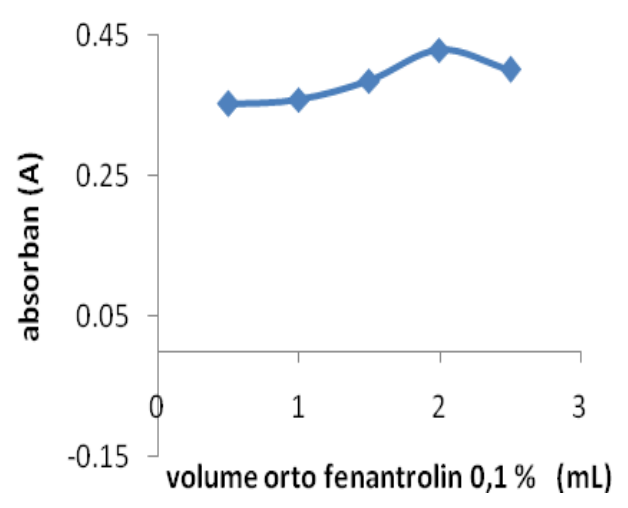

Gambar 4. Kurva pengaruh variasi jumlah orto-fenantrolin terhadap kestabilan kompleks Fe(II) orto-fenantrolin

Penyerapan maksimum yang terjadi pada volume orto-fenantrolin sebanyak $2 \mathrm{~mL}$. Volume yang lebih besar dari $2 \mathrm{~mL}$ mengalami penurunan absorban. Hal ini terjadi karena pada larutan yang orto fenantrolin 2,5 $\mathrm{mL}$ terdapat suspensisuspensi. Dimana suspensi-suspensi tersebut dapat menghambat penyerapan cahaya yang terjadi. Cahaya yang dihasilkan bukan diteruskan melainkan dihamburkan sehingga yang terbaca dimonokromator akan sedikit.

Tiga molekul orto-fenantrolin bergabung dengan satu molekul $\mathrm{Fe}(\mathrm{II})$ membentuk ion kompleks berwarna merah jingga seperti ilustrasi pada Gambar 5.

\section{Kurva Kalibrasi Larutan Standar $\mathrm{FeCl}_{3} \cdot \mathbf{6} \mathrm{H}_{2} \mathrm{O}$}

Konsentrasi yang digunakan untuk membuat kurva kalibrasi standar ialah $0 ; 0,002 ; 0,004$ ; 0.006 ; 0,008 M. (Gambar 6). Dari kurva kalibrasi standar didapatkan persamaan regresi $\mathrm{y}=95,85 \mathrm{x}+0,025$ dengan $\mathrm{R}^{2}=$ 0,992 . Dari persamaan regresi yang dihasilkan maka konsentrasi sampel dapat diketahui. Terdapat kelinieritas antara kosentrasi dengan absorban, yang dibuktikan dengan nilai $\mathrm{R}^{2}=0,992$.

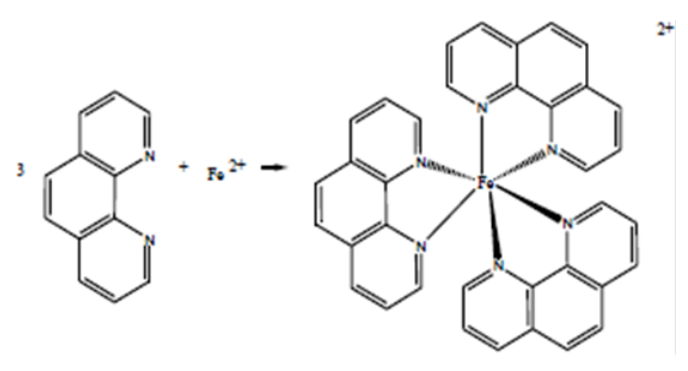

Gambar 5. Reaksi pembentukan kompleks $\mathrm{Fe}(\mathrm{II})$ orto-fenantrolin ${ }^{[8]}$.

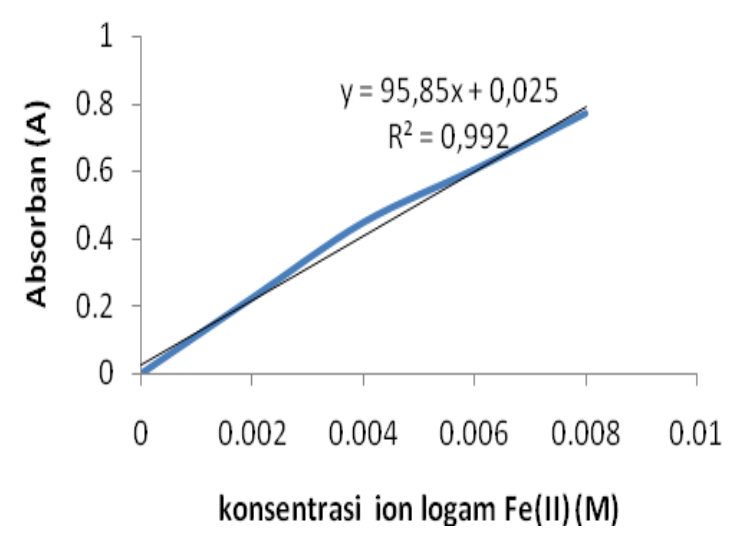

Gambar 6. Kurva kalibrasi larutan standar $\mathrm{FeCl}_{3} .6 \mathrm{H}_{2} \mathrm{O}$ 


\section{Penentuan Kandungan Unsur Hara Besi dalam Sampel}

Penentuan kandungan dalam sampel dilakukan dalam kondisi optimum dengan waktu kestabilan 60 menit, $2 \mathrm{~mL}$ ortofenantrolin, buffer asetat $\mathrm{pH} 4,5$, dengan panjang gelombang $515 \mathrm{~nm}$, dan $0,01 \mathrm{M}$ asam sitrat sebagai pereduksi.

Gambar 7 memperlihatkan kadar unsur hara besi dalam campuran tanah dan kompos selama 75 hari waktu inkubasi. Kadar unsur hara besi yang didapatkan ialah kadar Fe total dari campuran tanah dan kompos tersebut. Hasil yang didapat tersebut telah memenuhi SNI kompos (SNI 19-7030-2004). Menurut SNI tersebut kandungan $\mathrm{Fe}$ maksimal tersebut ialah $2 \%{ }^{9} \mathrm{pH}$ dari buffer asetat yang digunakan 4,5 tersebut sesuai dengan pH tanah yang stabil pada 4,1-4,9.

Terjadi penurunan kadar logam Fe setelah 30 hari disebabkan karena logam $\mathrm{Fe}$ didalam tanah tidak stabil dan kandungan unsur hara didalam tanah juga dapat terdegradasi sehingga mengurangi kadar logam Fe yang diinginkan.

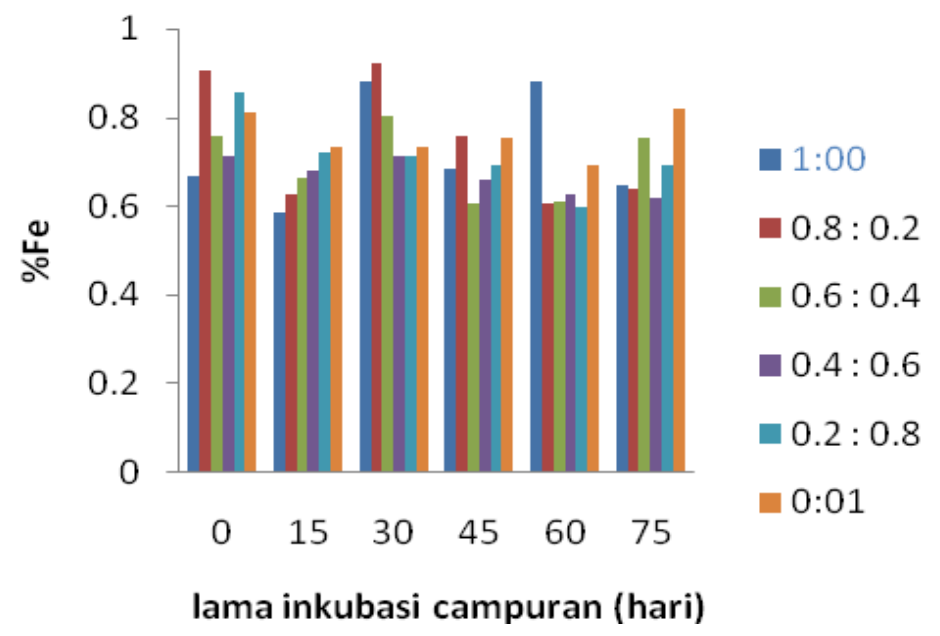

Gambar 7. Kandungan unsur hara besi pada sampel dengan berbagai variasi waktu dan perbandingan komposisi. Dimana, $\boldsymbol{\square}=1: 0$ (tanah:kompos); $=0,8: 0,2$ (tanah:kompos); $=$ 0,6:0,4 (tanah:kompos); $\square=0,4: 0,6$ (tanah:kompos), $\square=0,2: 0,8$ (tanah:kompos); dan $\square=0: 1$ (tanah:kompos)

Kandungan unsur hara besi yang tertinggi dapat dilihat pada komposisi tanah:kompos yaitu 0,8:0,2 30 hari waktu inkubasi yakni sebesar $0,92 \%$. Kandungan unsur hara besi terendah pada campuran tanah : kompos (1:0) pada hari ke 15 sebesar $0,58 \%$.

\section{KESIMPULAN}

Kadar unsur hara besi dalam campuran tanah:kompos tertinggi pada perbandingan 0,8:0,2 sebesar $0,92 \%$ dengan waktu inkubasi 30 hari. Kandungan terendah pada campuran 1:0 pada waktu inkubasi 15 hari yaitu sebesar $0,58 \%$. Kadar unsur hara besi yang didapatkan memenuhi SNI kompos yakni maksimal 2,00\%.

\section{DAFTAR PUSTAKA}

1. Yuli, A.F., Indrawati, and Refilda. Penentuan Kandungan Unsur Hara Mikro ( $\mathrm{Zn}, \mathrm{Cu}$, Dan $\mathrm{Pb}$ ) Didalam Kompos yang Dibuat dari Sampah Tanaman Pekarangan dan Aplikasinya pada Tanaman Tomat (Solanium lycopersicum Mill). Jurnal Kimia Unand 2 (2013) 34-40.

2. Muhammad, R.F.Z.Y.H., Indrawati., and Rahmiana, Z. Analisis Warna, Bau, pH, 
Fe, Zn, dan N-Organik pada Kompos yang Dibuat dari Tandan Kelapa Sawit dengan menggunakan Aktivator Lumpur Aktif PT. Bumi Sarimas Indonesia (Cocomas). Jurnal Kimia Unand 2 (2013) 36-43.

3. Dragica, L., Zoran, O., Ljubica, F., Dragana, B., Branko, S., Penavin, S., and Slavica, S. Stability Of Tris-1,10Phenanthroline Iron (II) Complex In Different Composites. Jurnal Chemical Industry \& Chemical Engineering Quarterly 16 (2010) 193-198.

4. Tee, ES, Khor, SC., and Siti, MZ. Determination of Iron in Food by the atomic Absorption Spectrophotometric and Calorimetric Methods. Jurnal Pertanika 12 (1989) 313-322.

5. Supriyanto and Zainul K. Penentuan Kadar $\mathrm{Cu}, \mathrm{Fe}, \mathrm{Zn}$, dalam tanah, tanaman teh, daun teh, dan minuman teh. ISSN 1410-6957 (2006).

6. Jeffery, G.H., Bassett J., mendham J., Denny R.C., Vogel Textbook of Quantitative Chemical Analysis, Fifth Edition. The School of Chemistry: London (1989).

7. Sandel, E,B., Colorimetric Determination of Traces of Metals, $3^{\text {rd }}$ ed, Interscience Publishers Inc, London : New York (1959).

8. Dinararum, R.R and Sugiarso, D. Studi Gangguan Krom (III) pada Analisa Besi dengan Pengompleks 1,10-Fenantrolin pada $\mathrm{pH}$ 4,5 secara Spektrofotometri UV-Tampak. Jurnal sains dan seni pomits, 2 (2013) 2337-352.

9. Badan standarisasi nasional, SNI 197030-2004, Spesifikasi Kompos Dari Sampah Organik Domestik 